\title{
Cost Assessment of preconstruction phase for Construction Projects in Egypt
}

\author{
Emad Abdel-Galil ${ }^{1} /$ Ahmed Hussein ${ }^{2} /$ Ahmed alborkan $^{3}$
}

\begin{abstract}
The main premise of transaction cost economics is that project cost is not only production costs but there are also additional costs resulting from transactions between parties. Transaction costs include _but are not limited to_the costs of preparing the bidding package, estimating and drawing up a contract, administering the contract, dealing with any deviations from contract conditions and any contractual problems include claims, change orders, and disputes. The main objective of this paper is to establish the factors that affecting transaction costs in construction projects in Egypt. The study was conducted on various types of construction projects in Egypt, which formed the sample size. To collect data, a questionnaire was used that was personally administered to the respondents, using emails and conducting semistructured interviews. The collected data were analyzed by using SPSS program, and a software package named IBM.

The findings indicated that the most important factors affecting positively (decreasing transaction cost value) on transaction cost value in construction projects in Egypt are:

1 - The good financial position of the contractor

2- Lack of claims by the contractor

3- Non-substitution of materials during implementation by contractor

4- Contractor's experience in similar type projects

5- The good relationship between the contractor and previous clients

6- Choose a more qualified contractor to do the job

7- The good relationship between the owner and contractor, designers, suppliers and government agencies

8- Implementation of the project in a stable security circumstance

9- Owner's obligation to pay the contractor in time

10- The high efficiency of communication between project parties

11- Owner's commitment to his orders and not change during execution

12- The high efficiency of the owner's organization

13- Choose the appropriate procurement method

14- Calculate the project time correctly

15- Choose the appropriate delivery type
\end{abstract}

Keywords: Transaction costs, pre-transaction costs, post-transaction costs, construction management, construction project.

\section{INTRODUCTION}

Construction projects are expected to be completed in certain objectives, time, and cost that have been previously identified. These requirements are often competing for a project. More ambitious usually leads to more time and higher cost assigned to the project, also more severe restriction is put in terms of time causes an increase in costs or decrease the quality of the final product requirements. Finally, a fixed budget result in more time wasted for the project and also low requirements. Therefore, the management cost of the project must take into account other aspects of the project.

\footnotetext{
${ }^{1}$ Professor of concrete structures, Faculty of Engineering, Port Said University, Egypt, Email: emad0057@eng.psu.edu.eg

${ }^{2}$ Associate Professor, Faculty of Engineering, Zagazig University, Egypt, Email: mekky1999@gmail.com

${ }^{3}$ Demonstrator, Civil Engineering, a Higher Institute of engineering and technology in New Damietta, Egypt, Email: dr.eng88@yahoo.com.
}

Project management is a process that involves estimating, planning and controlling costs so that the project does not exceed the budget. Project cost expresses effort and manpower that used in the construction of an object, cost overruns or delay in delivery time are the most serious problem that construction projects face because it's affecting the whole organization.

Not only cost overruns or failure lead times are the reason for significant deviations compared to original estimates, this direction will be discussed in this paper trying to find factors that affect transaction costs and study the extent of their impact.

According to the Standish group published reports, the exceeded project costs are frequently between $21 \%$ and 100 percent ( $60 \%$ of project cost overruns). Also, $4 \%$ of projects had cost overruns that lead to the final cost of 
the project to be more than four times originally estimated. According to Standish Group, analysis of construction projects in the UK has revealed deviations of costs between 50 and $80 \%$ and that means a lot for a building project(Simion-Melinte)

Figure 1 shows the share of project cost overruns.
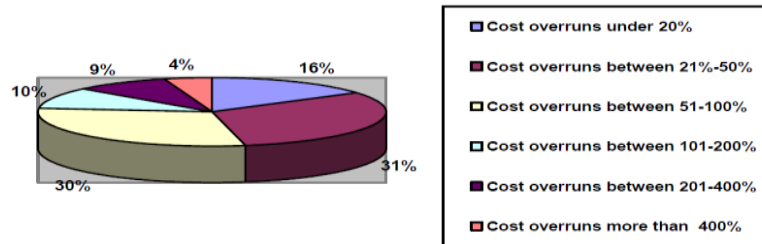

Fig 1: The share of project cost overruns reportedly CHAOS (Simion-Melinte)

Although each project is unique and has a special nature, in general, project cost management includes some subprocesses such as resource planning, cost estimating, create a budget, and finally cost control(DRURY 2013).

\section{Transaction costs in construction projects}

The main postulate of transaction cost economics is that, besides the costs of production, there are also additional costs that result from transactions between parties(Alston and Gillespie,1989). In 1975, Williamson identified asset of environmental and human factors which when combined together under a circumstance, make the transaction more costly. The transaction costs of any act of market exchange will depend on the interplay between different sets of human factors and environmental factors(Greenwood and Yates 2006).

When the cost of a project is estimated, there is always an uncertainty to all condition surrounded the project, how work will be performed, what work conditions will be like when the project is executed and so on. These uncertainties are risks to the project and may cause addition costs and threat the total cost of the project. Some refer to these additional costs as transaction costs.

The magnitude value of transaction costs in construction projects varies with many factors related to the characteristics of the project such as project delivery systems including; design-bid-build, design-build, and construction management. Also, procurement method includes competitive closed bidding, competitive open bidding, and negotiation, types of contracts also affected transaction value including lump sum, unit price, and cost-plus-fee contracts, even the type of the sector which is private or public. Not only the characteristics of the project affecting the transaction costs value but also human factors include owner and contractor, the role of the owner and contractor will extend to conflict, disputes, claims and change orders and so on.

\section{Overview of transaction cost economics (TCE)}

Neoclassical Economic Theory is based on the assumption of an "ideal world" in which the price mechanism exists and the trading value is determined based only on the supply and demand factors. In this case, the buyer and the supplier reach an agreement without any negotiation because the price is already known before. In the realworld, the matter is not simple like that; the exchange of goods and service is fairly complex. In the "real economy," if the appropriate price is measured, buyers often face different prices for the same good, even in a competitive market. This variation is likely to affect the market (Benham and Benham 2001; Barzel 1982).

Transaction Cost Theory tries to explain what Neoclassical Economics failed to consider and what classical economic ignored like bounded rationality, uncertainty, asset specificity and opportunism behavior in the "real world". The purpose of this paper is to provide a broad picture of transaction costs: their history, definition, foundation, use, measurement, and implications.

Ronald Coase is considered the most important and the most prominent person in the study of transaction cost economics, In his first paper in 1930, the businessmen were discussed about business methodologies they used, asking them about why firms sometimes produce some of their own inputs and other times decide to use and buy the market (Hazlett 1997; Herman 1997). In 1937, Coase published his new paper "The Nature of the Firm," which explain the basic economics of a business enterprise and determine how firms can pursue efficiency in a complicated world. This paper became one of the most influential works in the history of the economicscience. In 1960, Coase rearranged the study of economics in his paper "The Problem of Social Cost." It analyzed what happens when economic actions affect third parties.

Although transaction cost theory was introduced about 80 years, it is still facing many troubles, the most important problem is that there is no standard terminology (Benham and Benham 2001; Williamson 1981). Many different definitions are used in the literature but it is not used to measure transaction costs.

There are two fundamental branches of literature that have tried to explain and define transaction costs in an economic context. The first one is the Coasian approach which focuses on the quantification of transaction costs and the impact on the volume of trade. The second branch is the New Institutional Economics (NIE) approach propagated by Williamson which emphasizes the design of institutions and contracts to minimize unobservable transaction costs that are not directly quantified(Antinori and Sathaye 2007). These two approaches form a basis for establishing an analytical framework but they require adaptation for defining and quantifying transaction costs in construction projects.

\section{Transaction cost definition}

In transaction cost economics, a transaction occurs when a good or service is transferred across a technologically separable interface (Williamson 1981). By examining the previous literature, it is clear that there is a lack of 
standard terminology for defining transaction costs. Whereas some researchers call it procurement cost, others call it contract cost. Transaction costs are different from production costs, whereas production costs are the costs of transforming inputs into outputs, so transaction costs arise from economic exchange. The concept of transaction cost is not universally accepted by all participants in the construction industry and has not received much recognition by modern practice.

Coase (1937) was the first one who tried to define transaction costs; Coase defined transaction costs as "costs using price mechanisms associated with specifying, negotiating, and enforcing contracts." Ceases emphasized that the actual cost of a construction project is not the only production cost. The costs of preparing a bidding document, estimating, drawing up a contract, administering the contract, and dealing with any deviations from contract conditions are also important. These costs are known as transaction costs in the study of economic organizations.(Clough, Sears, and Sears 2000)

In the following years, Niehans (1969) tried to explain what is meant by the term "transactions costs" or "transfer costs" and defined it as the costs associated with the transfer of ownership from one individual to another. The parties have to communicate, information will be exchanged, contracts are drawn up, the goods must be inspected, weighed and measured, and accounts have to be kept. To a certain extent transactions involve additional transportation in space over and above what is required to move goods from producer to consumer "(Niehans 1969). In the same year, Arrow (1969) defined transaction costs as "the costs of running the economic system".

Although Niehans definition is a catchall term for a rather heterogeneous assortment of costs, Klaes 2000 have two points in Niehans definition. The first one is that transaction costs are defined in a very broad way. The second point, no distinction is made between transaction costs and transport costs.

Williamson 1974 defined transaction costs as "The costs of writing and executing complex contracts across the market vary with the characteristics of the human decision makers who are involved with the transaction on the one hand, and the objective properties of the market on the other ..." (Williamson 1979)

From the point of view of Klaes, Williamson not only elaborated the concept of transaction costs but he replaced it with a detailed analysis of contractual and organizational arrangements. In 1985, Williamson defined transaction costs to include the costs of drafting, negotiating and enforcing an agreement, and also the costs of governance and bonding to secure commitments.

Unlike the previous approaches where transaction costs have an exact value, Williamson's approach provides the notion that transaction costs have relative values and can be different from one market to another or from one organization to another. Williamson's analysis takes place as an exploration of the causes which give rise to transaction costs (Klaes 2000).

Joskow (1985) defined transaction costs as the costs of acquiring and processing information, legal costs, organizational costs, and costs associated with inefficient pricing and production behavior. Although, Davis (1986) defined transaction costs as those costs associated with "greasing markets," including the costs of obtaining information, monitoring behavior, compensating intermediaries, and enforcing contracts.

Alchian and Woodward (1988) tried to distinguish between two types of transactions; the first one is the exchange transactions involving the transfer of property rights, and the other one is the contracting transactions involving: negotiating and enforcing promises about performance.

North (1990) argued that transaction costs are the costs of measuring the valuable attributes of what is being exchanged and the costs of protecting rights and policing and enforcing agreements.

Rahman and Kumaraswamy (2002) claimed that transaction costs also involve costs associated with irregularities of contractual promises.

Farajian (2010) defined transaction cost to be the sum of the costs associated with searching for a contract, finding a partner, and engaging in exchange and contracting activities, which are separated from the direct costs of production. This inconsistency in definition and terminology results in inconsistency in data and renders data analysis almost impossible (Farajian 2010).

Arditi (2013) defined Transaction costs to include _but are not limited to_ the costs of preparing the bidding package, estimating, and drawing up a contract, administering the contract, dealing with any deviations from contract conditions and any contractual problems include claims, change orders, and disputes.

\section{Transaction costs in construction projects}

It appears that there is a need in the construction industry to define transaction costs in a manner that covers not only the pre-contract phase but also the construction phase of a project. It would also help in the event that the definition of transaction costs is accepted by all project participants (Li, Arditi, and Wang 2012).

In 2001 Turner and Simister concluded that: transaction costs incurred in all phases of a project are the costs of:

(1) Specifying the product in the tender documentation.

(2) Specifying the work methods in the tender documentation.

(3) Managing variations to the specification of the product during project delivery.

(4) Managing variations in the specification of the process during project delivery.

However, Hughes et al. (2006) classified transaction costs by project phase, namely pretendering (marketing, 
forming alliances, and establishing reputations), tendering (estimating, bidding, and negotiating) and posttendering (monitoring performance, enforcement of contractual obligations, and dispute resolution) costs.

Similarly, Whittington (2008) considered transaction costs in project phases from the time funds are initially allocated to the project to the process of publishing an advertisement, accepting bids, making an award, and the execution of the contract. According to Lingard et al. (1998), researchers should be close attention to the wide difference between the pre and post-contract transaction costs.

For construction projects, transaction costs in the construction phase may be much higher than transaction costs in the procurement phase (Lingard et al., 1998; Hughes et al., 2006; Turner and Simister, 2001; and Whittington, 2008). So this paper tries to defined transaction costs to cover both pre-contract and postcontract phase of a project.

\subsection{Pre-contract transaction costs}

Pre_contract transaction costs are incurred before a transaction takes place. It includes the costs incurred in the feasibility study, drafting and negotiating agreements and varies with the design of the good or service to be provided. Pre-contract transaction costs are defined as the transaction costs borne by the owner before the construction contract is signed.

Soliño and Gago de Santos (2009) tried to distinguish between external costs (such as technical, legal and financial advice) and in-house costs, such as project preparation costs. Soliño and Gago de Santos's (2009) pre-contract transaction costs include the costs of environmental impact assessment, feasibility study, preliminary design, and bidding include tender documentation preparation and negotiation. Soliño and Gago de Santos (2009) essentially agreed with Whittington's (2008) characterization.

Whittington (2008) found in six case studies that precontract transaction costs in the design-bid-build project delivery system range from $0.4-8.8 \%$ (average $2.6 \%$ ) of the value of the contract, and the range for the design/build project delivery system is $0-5.7 \%$ (average $2.2 \%)$.

Based on data collected from PPP projects financed by the European Investment Bank, Dudkin and Välilä (2005) concluded that transaction costs in the precontract phase of infrastructure projects are approximately $2-3 \%$ of the contract value on average. Also,Arditi (2013) found that pre_contract transaction costs include the costs of market research, exploring financing opportunities, conducting a feasibility study, bidding/ negotiation, and day-to-day pre-contract project management. Furthermore, respondents are asked to estimate the approximate cost of pre-contract transaction costs with respect to contract value in the last project they completed for their company/agency.

\subsection{Post-contract transaction costs}

Post-contract transaction costs consist of costs that afforded after the contract has been signed up till to the delivery of the construction to the owner.

According to Williamson (1985), post-contract transaction costs consist of "setup and running costs of the governance structure to which monitoring is assigned and to which disputes are referred and settled: the maladaptation costs that are incurred, the haggling costs that attend adjustments (or the lack thereof ), and the bonding costs of effecting secure(credible) commitments."

Yates (1999) agreed with Williamson view that postcontract transaction costs arising from disputes and litigation could be high. Conflict and disputes in the construction industries of many countries (including Australia, USA, UK, and Hong Kong) inflict a high cost to the industry in terms of direct and indirect costs. Direct costs include management time, and delays to project completion, in addition to costs of lawyers, and claims consultants. Indirect costs include abjection of working relationships, as a result of mistrust between participants.

Molenaar et al. (2000) concluded that the factors affecting disputes consistof (1) people issues; (2) process issues; and (3) project issues. People issues include organizations, relationships, roles, responsibilities, and expectations that affect these people. Process issues involve the manner in which the construction and contract are carried out. Project issues involve those characteristics that appointed the technical nature of the project.

Greenwood (2007) explained that transaction costs of any act of market exchange involve different sets of human factors and environmental factors. Since disputes have considered as the core of the post-contract transaction costs, many scholars made an effort to deeply study the factors that affect disputes.

Whittington (2008) found in six case studies that the post-contract transaction costs for the design-bid-build project delivery system range between 8.9 and $14.7 \%$ (average $12.6 \%$ ) of the contract value, and the range for the design/build project delivery system is 3.4-14.3\% (average $9.5 \%$ ). Post-contract transaction costs include the costs of day-to-day contract administration, administering claims and change orders, and dispute resolution, in addition to incentive payments (Arditi 2013).

In addition to Williamson and Yates definition,Arditi 2015 argued post-contract transaction costs to disputes resolution, litigation, conflict, and incentive payments and considering it the core of post-contract transaction costs.

In this paper, the factors affecting transaction costs are classified into two human-related categories: the owner's and the contractor's role in the transaction. Also the characteristics of the project will be taken into account. The four environment-related categories are: the transaction environment, transaction emergency, bidding environment, and project management efficiency 


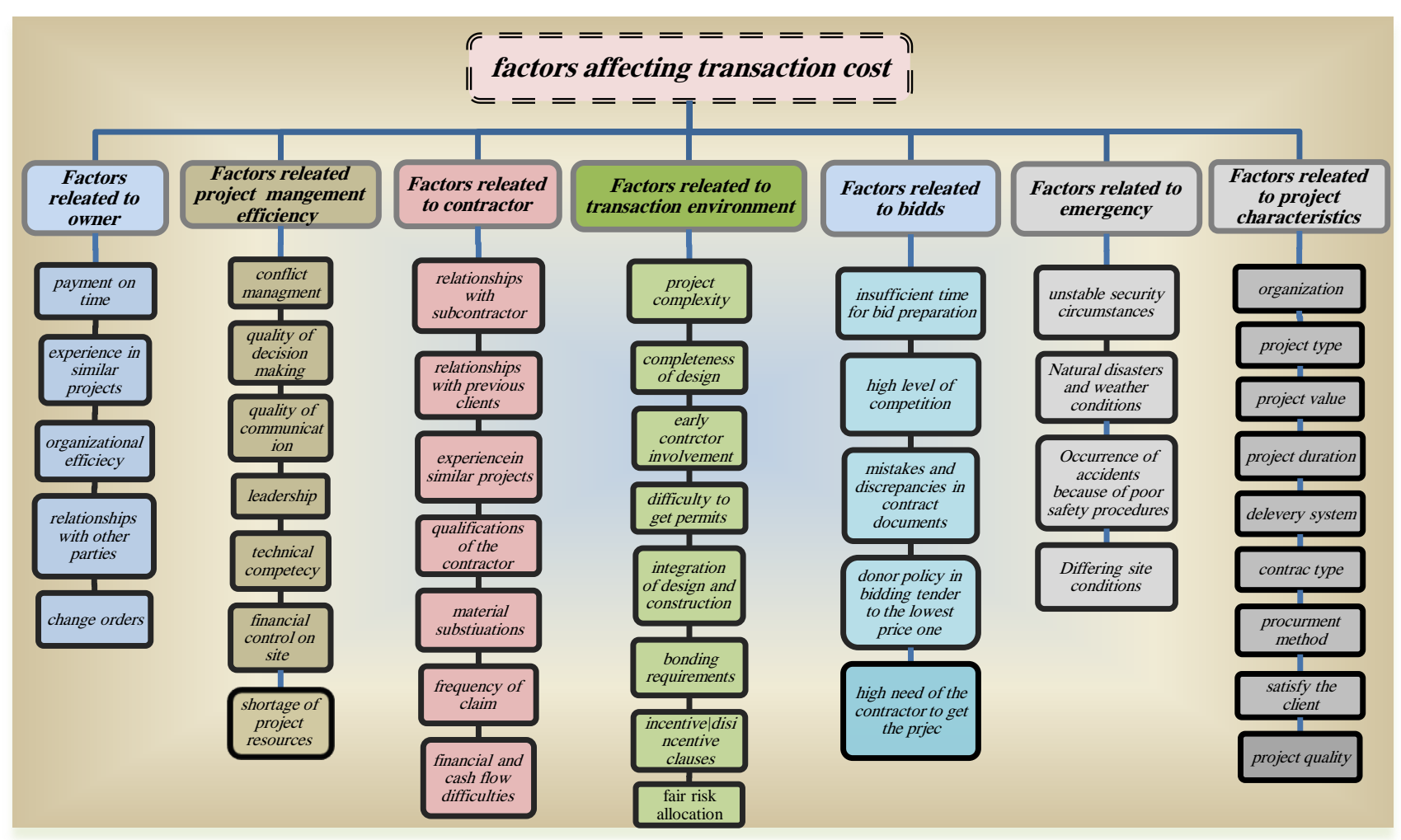

Fig 2: factors affecting transaction cost

\section{METHODOLOGY}

This research uses a questionnaire survey to collect the required data and study all factors collected and shown in fig 2, to detect the most affecting factors on transaction cost value. Data were collected through two main manners. Firstly, the questionnaire was designed for a response over a web link and was administered to a very large number of shareholders in the construction industry in Egypt (owners, consultants, and contractors).Secondly, the questionnaire was hold through a semi-structured interview with high experienced members in construction project management in construction organizations.

The potential respondents were selected to cover a large sector of construction activities in Egypt included: residential (houses, low-rise, and high rise apartment buildings), building (institutional, educational, light industrial, commercial, social, religious, governmental and recreational facilities), engineering (highway, sewage and water- treatment plants, dams, pipelines, ports and harbor, tunnels, bridges, telephone distribution, and pumping stations), industrial (petroleum refineries, steel mills, chemical plants, smelters, electric power generating stations, and heavy-manufacturing facilities).

For a large number of contributors in the construction projects in Egypt, it will be suitable to use the next equation to yield a representative sample size for a large number of contributors $\left(n_{0}\right)$.

$$
n_{0}=\frac{Z^{2} p q}{e^{2}}
$$

Where $Z^{2}$ is the abscissa of the normal curve that cuts off an area at the tails ( 1 - equals the intended confidence level, e.g., 90\%), e is the intended level of precision, $p$ is the evaluated proportion of an attribute that is presented in the contributors, and $q$ is $1-p$. The worth for $Z$ is found in the statistical tables which includes the area under the normal curve, $N$ pictured the quantity of shareholders in the construction process in Egypt.

The questionnaire review was carried out in Egypt, the contributors are 30900, which represent the quantity of contractors' works in construction projects in Egypt, and this quantity was obtained from the Egyptian Federation for Construction \& Building Contractors. The population is big; consequentlyequation 1 is applied first for finding out the sample size $\left(n_{0}\right)$. A confidence level, $90 \%$ is assumed, thus $Z=1.65$ from normality tables, $p$ is assumed $0.5, e$ is assumed $( \pm 15 \%)$. Substituting about: $Z, p, q$, and e in the prior equation, causes a sample size $n_{0}=30.25$

Since the participants in the construction process are not only contractors but also consultants and owners, so it can be considered that the size of the sample is three times the calculated proportion of contractors' i.e.

$$
n=30.22 * 3=90.66 \approx 91 \text {. }
$$

Respondents were required to rate (using a one to fivepoint Likert scale)the level of each variable in the questionnaire by taking into account the characteristics of their organization's last construction project in which they were involved. From December 2017 to March2018, up to 1500 e-mails were sent out. A total of 163 completed responses were returned for data analysis, a number of governing criteria have been developed for accepting answered questionnaires, the first criterion: appropriately 
enough time to answer the questionnaire has been identified by some experienced respondents, an approximate time was developed that is suitable to answer the questionnaire and the questionnaire that takes less time in answer was rejected. The second criterion: during the design of the questionnaire, it is taken into account that it is not possible to answer the questionnaire more than once for the same person or same device. The third criterion: during the questionnaire design, some exploratory questions had been put to check respondent seriousness. The questionnaire, which fails in one of these three criteria, will be rejected. According to these criteria, 145 answers were accepted and 18 were rejected, the rate of the accepted respondent is 89 percent.

An analysis of variance (SPSS) was used to test the effect of the different project characteristics on transaction costs, including different project organizations, different project delivery systems, different procurement methods, and different types of contracts. This analysis assumes that the observations in the samples are independent of each other and follow a normal distribution. It is safe to assume that the 145 observations in this study are normally distributed.

\section{Reliability of the questionnaire}

Reliability and validity are important aspects of a quantitative research inquiry. The reliability of constructs permits to measure set of factors that are internally consistent with their measurement, therefore, are repeatable for other researchers to measure (Hair et al. 2006).

Cronbach's alpha is a measure of the intercorrelation and reliability of items. It measures how well a set of items measures a single unidimensional latent construct. Theoretically, alpha varies from zero to 1 , because it is the ratio of two variances. Higher values of alpha are more desirable. A Cronbach's alpha coefficient of 0.70 at least is normally considered to indicate a reliable set of items (De Vaus 2002). George and Mallery (2003) provide the following rules of thumb: alpha $>0.90$ is excellent; alpha $>0.80$ is good; alpha $>0.70$ is acceptable; alpha $>0.60$ is questionable; alpha $>0.50$ is poor; and alpha $<0.50$ is unacceptable.

From analyzing the data separately, the results are as follows: for contractor's survey, Cronbach's alpha value was .812 for 22 items, for consultant's survey it was .715 for 23 items, and for owner's survey, Cronbach's value was .890 for 15 items.

From the previous results, all composite reliability values are larger than 0.70 . These results suggest that the questionnaire we have investigated achieves an internal consistency and expresses the construction community very well, almost to an excellent degree.

\section{Data analysis}

\subsection{Characteristics of the respondents and projects}

In all, 66.2 percent of the respondents were contractors, 17.24 percent were consultants, and the remaining 16.55 percent were owners.

The organization type of the respondents was divided into two main sections: the public sector that was 42.71 percent and the private sector that was 57.29 percent.

Years of experience are categorized into five groups with 5 years increments, on the average, respondents had more than 20 years of experience were represented 26.75 percent of respondents, and 47.42 percent of respondents having more than 10 years in the construction industry, given to the respondents' top and middle managerial level and their extensive professional experience, they are expected to have adequate knowledge about projects. So, their answers can be considered to be reliable.

It was essential that the study covers various types of construction projects. Therefore, projects have been classified into four main types; residential $36 \%$, building $33 \%$, engineering $23 \%$, and industrial $8 \%$.

The study has covered various times of projects. It is observed that most of the construction projects have time less than four years, but the study included a large construction project exceeds four years' time, fig 3 indicates the distribution of respondent's answer for project time.

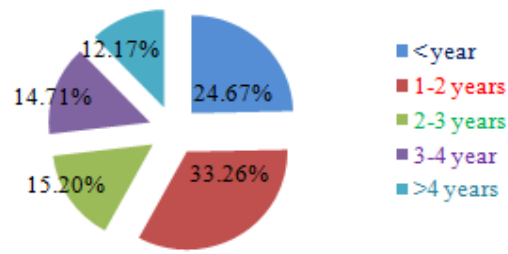

Fig 3: Project time

All project delivery systems include design-bid-build, design-build, and construction management are well represented in the survey sample. And it is clear that design-bid-build system is controlling the Egyptian market for the construction industry. As shown in fig 5, the study included various systems which contribute to give more accurate results.

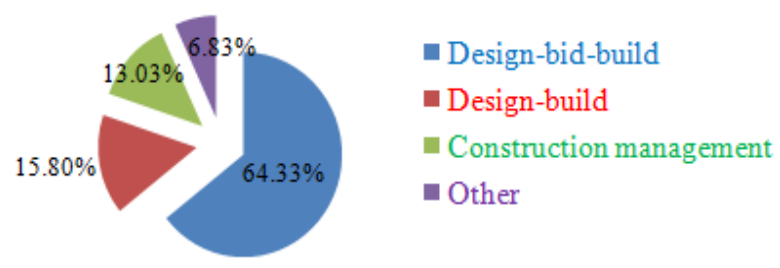

Fig 4: Project delivery systems

As shown in fig 5, all procurement methods are inquired in the study. Competitive bidding appears to be quite dominant for respondents because competitive bidding is required by law in public construction projects, while in private projects we find that competitive bidding system controlling because it helps the owner to get more benefit from contractors. While negotiating system presents also clearly in construction projects, due to the owners desire to achieve the maximum benefits, some 
other systems that have a significant representation in the Egyptian Construction Industry appears.

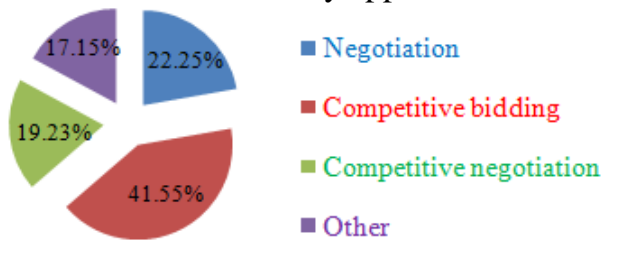

Fig 5: Project procurement methods

As shown in fig 6, all types of contracts including lump sum, unit price, and cost-plus-fee contracts were used in the projects covered in the survey, but it is clear that the unit price contract appears to be quite dominant.

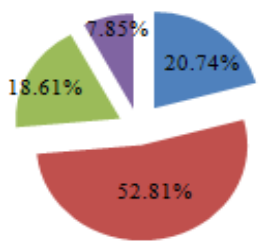

$$
\begin{aligned}
& \text { - Lump-sum } \\
& \text { - Unit-price } \\
& \text { n Cost-plus-fee } \\
& \text { - Other }
\end{aligned}
$$

Fig 6: contract type

\subsection{Pre-contract transaction costs value}

Respondents were asked to assess pre-contract transaction costs value as a percent of contract value using a Likert scale measure.

It is found that owners, consultants, and contractors approximately gave the same assessment of the value of pre-contract transaction costs. The average pre-contract transaction costs were 3.64 percent of the contract value, and it was easy to note that some of the contractors gave lower percentages to pre-contract value. This is because of the lack of direct contact between Contractors with pre-contract phase.

\subsection{Post-contract transaction costs value}

Respondents also were asked to assess post-contract transaction costs value as a percent of contract value using a Likert scale measure. Owners evaluated the postcontract transaction costs relatively higher than the consultants and contractors, and the average postcontract transaction cost was 4.74 percent of the contract value. The reason why transaction costs are much higher in the post-contract phase may be because the construction phase is longer in duration, it requires to coordinate large number of stakeholders and necessitates more complex project setup.

These results emphasize the findings of Lingard (1998), Turner and Simister (2001), Hughes (2006), Whittington (2008), and Huimin Li, David Arditi, Zhuofu Wang, (2014)

\section{$8.495 \%$ confidence interval test}

The quality of the results can be verified through the 95 confidence test, which confirms that the results obtained can be trusted by up to $95 \%$ and that if the study is repeated again we will get $95 \%$ on the same result,

\begin{tabular}{|c|c|c|c|c|}
\hline \multicolumn{5}{|c|}{ 95\% Confidence Interval for Mean (all data survey) } \\
\hline & & & Statistic & $\begin{array}{l}\text { Std. } \\
\text { Error }\end{array}$ \\
\hline \multirow{4}{*}{$\begin{array}{c}\text { pre_contract } \\
\text { transaction cost } \\
\text { value }\end{array}$} & \multicolumn{2}{|l|}{ Mean } & 2.26 & \multirow{4}{*}{.097} \\
\hline & \multirow{2}{*}{$\begin{array}{l}95 \% \text { Confidence } \\
\text { Interval for Mean }\end{array}$} & $\begin{array}{l}\text { Lower } \\
\text { Bound }\end{array}$ & 2.07 & \\
\hline & & $\begin{array}{l}\text { Upper } \\
\text { Bound } \\
\end{array}$ & 2.45 & \\
\hline & \multicolumn{2}{|c|}{$5 \%$ Trimmed Mean } & 2.19 & \\
\hline \multirow{4}{*}{$\begin{array}{l}\text { post contract } \\
\text { transaction value }\end{array}$} & \multicolumn{2}{|l|}{ Mean } & 2.20 & \multirow{4}{*}{.113} \\
\hline & $95 \%$ Confidence & $\begin{array}{l}\text { Lower } \\
\text { Bound } \\
\end{array}$ & 1.98 & \\
\hline & Interval for Mean & $\begin{array}{l}\text { Upper } \\
\text { Bound } \\
\end{array}$ & 2.43 & \\
\hline & \multicolumn{2}{|c|}{$5 \%$ Trimmed Mean } & 2.12 & \\
\hline \multicolumn{5}{|c|}{$95 \%$ Confidence Interval for Mean (owner) } \\
\hline \multirow{4}{*}{$\begin{array}{l}\text { pre_contract } \\
\text { transaction cost } \\
\text { value }\end{array}$} & \multicolumn{2}{|l|}{ Mean } & 2.30 & \multirow{4}{*}{.222} \\
\hline & \multirow{2}{*}{$\begin{array}{l}95 \% \text { Confidence } \\
\text { Interval for Mean }\end{array}$} & $\begin{array}{l}\text { Lower } \\
\text { Bound } \\
\end{array}$ & 1.84 & \\
\hline & & $\begin{array}{l}\text { Upper } \\
\text { Bound }\end{array}$ & 2.76 & \\
\hline & \multicolumn{2}{|c|}{ 5\% Trimmed Mean } & 2.23 & \\
\hline \multirow{4}{*}{$\begin{array}{l}\text { post contract } \\
\text { transaction value }\end{array}$} & \multicolumn{2}{|l|}{ Mean } & 2.22 & \multirow{4}{*}{.243} \\
\hline & $95 \%$ Confidence & $\begin{array}{l}\text { Lower } \\
\text { Bound } \\
\end{array}$ & 1.71 & \\
\hline & Interval for Mean & $\begin{array}{l}\text { Upper } \\
\text { Bound }\end{array}$ & 2.72 & \\
\hline & \multicolumn{2}{|c|}{$5 \%$ Trimmed Mean } & 2.14 & \\
\hline \multicolumn{5}{|c|}{ 95\% Confidence Interval for Mean (Consultant) } \\
\hline \multirow{4}{*}{$\begin{array}{l}\text { pre_contract } \\
\text { transaction cost } \\
\text { value }\end{array}$} & \multicolumn{2}{|l|}{ Mean } & 2.38 & \multirow{4}{*}{.223} \\
\hline & \multirow{2}{*}{$\begin{array}{l}95 \% \text { Confidence } \\
\text { Interval for Mean }\end{array}$} & $\begin{array}{l}\text { Lower } \\
\text { Bound } \\
\end{array}$ & 1.92 & \\
\hline & & $\begin{array}{l}\text { Upper } \\
\text { Bound } \\
\end{array}$ & 2.85 & \\
\hline & \multicolumn{2}{|c|}{$5 \%$ Trimmed Mean } & 2.31 & \\
\hline \multirow{3}{*}{$\begin{array}{l}\text { post contract } \\
\text { transaction value }\end{array}$} & \multicolumn{2}{|l|}{ Mean } & 1.86 & \multirow{3}{*}{.252} \\
\hline & \multirow{2}{*}{$\begin{array}{l}95 \% \text { Confidence } \\
\text { Interval for Mean }\end{array}$} & $\begin{array}{l}\text { Lower } \\
\text { Bound } \\
\end{array}$ & 1.33 & \\
\hline & & $\begin{array}{l}\text { Upper } \\
\text { Bound }\end{array}$ & 2.38 & \\
\hline
\end{tabular}

which is a positive indicator over results quality, the test result is as shown in table 1.

Table 1: $95 \%$ Confidence Interval test 


\begin{tabular}{|c|c|c|c|c|}
\hline & \multicolumn{2}{|c|}{$5 \%$ Trimmed Mean } & 1.73 & \\
\hline \multicolumn{5}{|c|}{ 95\% Confidence Interval for Mean (Contractor) } \\
\hline \multirow{4}{*}{$\begin{array}{c}\text { pre_contract } \\
\text { transaction cost } \\
\text { value }\end{array}$} & \multicolumn{2}{|l|}{ Mean } & 2.18 & \multirow{4}{*}{.120} \\
\hline & \multirow{2}{*}{$\begin{array}{l}\text { 95\% Confidence } \\
\text { Interval for Mean }\end{array}$} & $\begin{array}{l}\text { Lower } \\
\text { Bound }\end{array}$ & 1.94 & \\
\hline & & $\begin{array}{l}\text { Upper } \\
\text { Bound } \\
\end{array}$ & 2.42 & \\
\hline & \multicolumn{2}{|c|}{$5 \%$ Trimmed Mean } & 2.13 & \\
\hline \multirow{4}{*}{$\begin{array}{l}\text { post contract } \\
\text { transaction value }\end{array}$} & \multicolumn{2}{|l|}{ Mean } & 2.28 & \multirow{4}{*}{.142} \\
\hline & 95\% Confidence & $\begin{array}{l}\text { Lower } \\
\text { Bound }\end{array}$ & 2.00 & \\
\hline & Interval for Mean & $\begin{array}{l}\text { Upper } \\
\text { Bound }\end{array}$ & 2.57 & \\
\hline & \multicolumn{2}{|c|}{ 5\% Trimmed Mean } & 2.20 & \\
\hline
\end{tabular}

\section{Most Important Factors}

Data were analyzed using frequencies, average scores, standard deviations, percentages, person correlation factor and Cronbach's alpha coefficient; analysis result confirmed that it seems to be a certain degree of interdependence among the factors that were determined in the questionnaire and the value of transaction costs. Significant correlation factors that have more than 0.2 person correlation have been accepted tentatively to be chosen and to identify the most influential elements using regression analysis.

Correlation factor between transaction costs and the tested factors are listed in table 2 .

Table 2: Correlation factor between transaction costs and the tested factors

\begin{tabular}{|c|c|c|c|c|}
\hline & factors affected transaction cost & $\begin{array}{c}\text { Factor-related } \\
\text { to }\end{array}$ & $\begin{array}{c}\text { Pearson } \\
\text { Correlation } \\
\end{array}$ & $\begin{array}{l}\text { Sig. (2- } \\
\text { tailed) }\end{array}$ \\
\hline 1 & the contractor have a good financial position & contractor & $.660 . * *$ & 0.001 \\
\hline 2 & The contractor rarely filed claims & Contractor & $.606-^{* *}$ & 0.002 \\
\hline 3 & The contractor made a few material substitutions & Contractor & $-.576-* *$ & 0.004 \\
\hline 4 & The contractor was experienced in similar type projects & Contractor & $-.575-* *$ & 0.004 \\
\hline 5 & $\begin{array}{l}\text { The contractor's relationship with previous clients was } \\
\text { excellent }\end{array}$ & Contractor & $-526-* *$ & 0.01 \\
\hline 6 & the contractor was qualified to do the job & Contractor & $-505 . *$ & 0.02 \\
\hline 7 & procurement method & $\begin{array}{c}\text { project } \\
\text { charactenistics }\end{array}$ & $-480^{*}$ & 0.028 \\
\hline 8 & $\begin{array}{l}\text { The owner had a good relationship with the contractor, } \\
\text { designers, suppliers and govemment agencies }\end{array}$ & owner & $-456 \cdot *$ & 0.038 \\
\hline 9 & Project time & $\begin{array}{c}\text { project } \\
\text { charactenistics }\end{array}$ & $.385^{* *}$ & 0.001 \\
\hline 10 & project value & $\begin{array}{c}\text { project } \\
\text { characteristics }\end{array}$ & $.333^{\circ}$ & 0.019 \\
\hline 11 & Delivery Type & $\begin{array}{c}\text { project } \\
\text { characteristics }\end{array}$ & $.307^{* *}$ & 0.009 \\
\hline 12 & uncertainty relative to unstable security circumstance & emergency & $.293^{*}$ & 0.012 \\
\hline 13 & owner paid contractors and suppliers in time & Owner & $.265^{*}$ & 0.022 \\
\hline 14 & the efficiency of Communication with other parties & $\begin{array}{l}\text { management } \\
\text { efficiency }\end{array}$ & $.264^{*}$ & 0.031 \\
\hline 15 & achieved required quality & $\begin{array}{c}\text { project } \\
\text { characteristics }\end{array}$ & $.259 *$ & 0.033 \\
\hline 16 & the owner rarely issued change orders & owner & $.256^{*}$ & 0.031 \\
\hline 17 & satisfy the client & $\begin{array}{c}\text { project } \\
\text { charactenistics }\end{array}$ & $.245^{*}$ & 0.043 \\
\hline 18 & the efficiency of the owner's organization was high & owner & $.235^{*}$ & 0.045 \\
\hline
\end{tabular}

Factors that have a correlation coefficient greater than .5 are the most influential elements which have a direct and strong impact on transaction cost value, while lower coefficient means that the factor is less effective on transaction cost value.

\section{- $\quad$ Factors related to contractor}

From results shown in table 2, it is founded that the elements that occupy the top six positions in the ranking are related to contractor, the matter which clarifies to what extent the contractor affects transaction cost value. It confirms the result of the measurement model that the path coefficient for a contractor is the highest between all paths with 0.516 value.

\section{- $\quad$ Factors related to project characteristics}

Factors related to the project characteristics are ranked second in terms of the value of the path coefficient with 0.38 , and there are six elements of this group within the elements of the high impact on transaction cost value.

\section{- $\quad$ Factors related to the owner}

The owner also has an obvious impact on transaction cost value, factors related to the owner have a path coefficient of 0.17 and also there are four elements related to the owner within the most influential factors on transaction costs value.

\section{- $\quad$ Factors related to emergency}

Factors related to emergency have an effect on transaction cost value. This effect is because the study was carried out in the period after January Revolution and the unstable security conditions. This group has a path coefficient of 0.13 , and the most influential element of this group was "unstable security circumstances" factor.

\section{- $\quad$ Factors related project management efficiency}

Factors related project management efficiency, this group has a 0.09 value of a path coefficient that's referring to its weak effect on transaction cost value. But "the efficiency of communication with other parties" remains one of the factorsthat have a high influencing on transaction cost value.

\section{- $\quad$ Factors related to bids}

Factors related to bids seem to be the least influential group among all groups, where it has a path coefficient 0.05 value, and none of its elements were found to be the most influential factors on transaction cost.

\section{Discussion of Factors and How to Measure}

1-Financial and cash flow difficulties of the contractor

Shortage of cash flow and financial difficulties may cause project delays or cost overruns that will lead to high transaction costs. This indicator can be assessed by checking the financial situation of the contractor through the documents submitted for tender.

\section{2- Contractor's frequency of claims}

Claims may be settled amicably, but some can degenerate into unnecessary conflicts and disputes 
(Kumaraswamy 1997) and, in turn, transaction costs increase. This indicator can be assessed by tracking the number of claims filed by the contractor in the previous projects.

\section{3- Contractor makes a material substitution}

Frequent material substitutions may cause frequent claims, fluctuations in product costs, and higher transaction costs. The number of material substitution requests filed by the contractor will be a good indicator for this stander.

\section{4- Contractor's experience in similar type projects}

A company that performed well in previous projects will be expected to do well also in the next work due to its experiences, and to lower transaction costs. The number of similar completed projects will indicate the extent of its experience in similar projects.

\section{5- Contractor's relationships with previous clients}

Smooth relationships with previous owners may enhance cooperation and trust between owners and contractors, and create stability in the contractor's behavior, hence lowering transaction costs. The references provided by past owners can measure this indicator.

\section{6- Contractor's qualifications}

It is concerned with the extent of the ability of the contractor to do the work required, and its ability to adhere to do the work within the budget and schedule, an efficient contractor helps to complete work without problems with lower transaction costs. Bonding requirements set by an owner largely reflect a measure of this indicator.

\section{7- Procurement method}

Awarding a contract by negotiation generates the lowest pre-contract transaction costs when compared to competitive bidding. The transaction expected to be affected by the selected procurement method.

\section{8- Owner's Relationships with other parties}

A good relationship between the parties will help to reduce the uncertainty in the transaction environment, which in turn devolve to reduce transaction costs(Hobbs 1996). Frequency and severity of conflicts can be regarded as an appropriate standard for measuring this indicator.

\section{9-Project duration}

Project duration considered as one of the most affecting factors for project cost, when the project duration is long, the contractor may face many troubles affecting his targeted costs, such as fluctuation of resources price, shortage of cash flow, long project duration limits the chance of the contractor to get new works during project execution. On the other side, short project duration may cause project delay, forcing the contractor to pay liquidated damages amount that may make the project vulnerable to claims and cause further delays and further cost, both very short and too long project duration have a significant impact on increasing the value of transaction costs. This indicator can be assessed by tracking the history of the too long and very short-term projects and the number of issues related to project duration.

\section{0- Project value}

Projects that have a high value may involve more than one company in implementation, which may lead to internal conflicts between those companies. On the other hand, the expansion of the focus of work may lead to slow decision, also when a malfunction occurs in a particular part of the project, this may cause the entire project to be malfunctioning, resulting in specific timespecific problems. Project capital can be a real indicator of this element.

\section{1- Delivery system type}

Project delivery is defined as the contractual relationships between the owner, architect/engineer, contractor, and the management services utilized to design and construct a project, the transaction costs incurred in construction projects are expected to be affected by the delivery system selected.

\section{2-Unstable security circumstances (revolutions)}

Unstable political and security situations result in working at dangerous area will lead to a shortage of materials at local market; the price of many materials will increase dramatically. This indicator can be assessed by tracking the political situation and its impact in the course of the project.

\section{3- Owner paid contractors and suppliers in time}

Timely payments by the owner will reduce uncertainty, lead to fewer claims, and reduce the frequency and magnitude of legal disputes. Owner's track record in the past projects in the amount of legal disputes concerning the delay in the payment of the contractors should be a good measure of this indicator.

\section{4- Efficiency of communication with other parties}

The quality of communication allows the parties for understanding the goals of the project organization easily, the roles and responsibilities of all the members, and the speed of information flow, which in turn reducing of conflicts, that leads to a reduction of transaction costs. This indicator can be assessed by analyzing the number and content of emails, text messages, and telephone calls between the parties or by using specialized project management software such as Autodesk Construct ware or Primavera Contract Management.

\section{5-Achievedrequired quality}

Achieving the required quality may indicate many points, including the efficiency of the contractor and the degree of clarity of the owner in determining his requirements, which necessarily reduces the occurrence of problems and claims, resulting in lower transaction costs. This indicator can be measured by the tracked owners' point of view of the last few projects that implemented by the same contractor.

16- Owner change orders 
Many change orders will increase the uncertainty in the owner's behavior that will lead to increase the magnitude of transaction costs. This indicator can be measured by the frequency and magnitude of change orders that had asked from owner during project implementation.

\section{7- Satisfy the client}

Owner satisfaction with the performed works and with contractor handling may indicate the efficiency of the contractor, which reduces the occurrence of problems and claims that leading to low transaction costs. This indicator can be measured by the tracked owner's point of view of the last few projects that the same contractor implemented.

\section{8- Owner organizational efficiency}

A stable and efficient organization is likely to allow a smooth operation and more stable environment, and finally lead to reduce transaction costs. Using Powell scale owner organizational efficiency can be tracked.

\section{CONCLUSIONS}

Factors that affecting transaction costs are classified into two human-related categories: factors related to owner, and factors related to contractor. Also the characteristics of the project will be taken into account "factors related to project characteristics", and there are four environment-related categories: the transaction environment, transaction emergency, bidding environment, and project management efficiency.

\subsection{Factors related to contractor}

From the shown table, it is founded that the elements that occupy the top six positions in the ranking are related to contractor, the matter which clarifies to what extent the contractor affects transaction cost value. It confirms the result of the measurement model that the path coefficient for a contractor is the highest between all paths with 0.516 value.

\subsection{Factors related to project characteristics}

Factors related to the project characteristics are ranked second in terms of the value of the path coefficient with 0.38 , and there are six elements of this group within the elements of the high impact on transaction cost value.

\subsection{Factors related to the owner}

The owner also has an obvious impact on transaction cost value, factors related to the owner have a path coefficient of 0.17 and also there are four elements related to the owner within the most influential factors on transaction costs value.

\subsection{Factors related to emergency}

Factors related to the emergency have an effect on transaction cost value. This effect is because the study was carried out in the period after January Revolution and the unstable security conditions. This group has a path coefficient of 0.13 , and the most influential element of this group was "unstable security circumstances" factor.

\subsection{Factors related project management efficiency}

Factors related project management efficiency, this group has a 0.09 value of a path coefficient that's referring to its weak effect on transaction cost value. But "the efficiency of communication with other parties" remains one of the factorsthat have a high influence on transaction cost value.

\subsection{Factors related to bids}

Factors related to bids seem to be the least influential group among all groups, where it has a path coefficient 0.05 value, and none of its elements were found to be the most influential factors on transaction cost.

Based on the findings of this paper, transaction costs value borne in construction projects can be minimized if the following attributes have been achieved in the project:-

- Contractor who carries out the project has a good financial position.

- All indicators confirm that the contractor is qualified to carry out the project.

- It is also necessary for the contractor to have a sufficient experience in previous similar projects

- The contractor should have good relations with the previous owners who have dealt with them before

- The contractor is always committed to the materials included in the specifications and does not replace them.

- The contractor should not resort to a lawsuit much.

- The owner must have good relationships with the parties involved in the project

- the extent of the owner's obligation to pay contractor and suppliers on time has a significant impact on transaction cost value

- Owner organization efficient should be high

- The owner's commitment to predefined orders and not constantly changing it

- Choosing the appropriate procurement method and delivery type also plays an important role.

- Project value and project duration are factors that must be carefully calculated if we want to reduce transaction cost value

- Creating a highly efficient communications system among all parties involved in the project, which works to speed up the solution of obstacles and find solutions that may lead to a low transaction cost value.

- Finally, it must be consider that trying to obtain the highest possible quality and trying to satisfy the customer is always accompanied by an increase in transaction cost value. 
What distinguishes this study from previous studies is that this study considered the transaction costs that were borne by the owner not only in terms of the total but also considered the value of transaction costs in the pre- and post-contract stages separately and also studied the factors that affect it.

\section{REFERENCES}

Alston, Lee J, and William Gillespie. 1989. 'Resource coordination and transaction costs: A framework for analyzing the firm/market boundary', Journal of Economic Behavior \& Organization, 11: 191-212.

Antinori, Camille, and Jayant Sathaye. 2007. 'Assessing transaction costs of project-based greenhouse gas emissions trading', Lawrence Berkeley National Laboratory, Berkeley, California.

Barzel, Yoram. 1982. 'Measurement cost and the organization of markets', The Journal of Law and Economics, 25: 27-48.

Benham, Alexandra, and Lee Benham. 2001. 'The costs of exchange', 2000): Institutions, Contracts and Organizations: Perspectives from New Institutional Economics, Edward Elgar, Cheltenham: 367-75.

Clough, Richard H, Glenn A Sears, and S Keoki Sears. 2000. Construction project management (John Wiley \& Sons).

DRURY, COLIN M. 2013. Management and cost accounting (Springer).

Greenwood, David, and DJ Yates. 2006. 'The determinants of successful partnering: a transaction cost perspective', Journal of Construction Procurement, 12: 422.

Hazlett, Thomas W. 1997. 'Looking for results: Nobel laureate Ronald Coase on rights, resources, and regulation', Reason: 40-46.

Herman, Edward S. 1997. Triumph of the market: Essays on economics, politics, and the media (Black Rose Books Ltd.).

Hobbs, Jill E. 1996. 'A transaction cost approach to supply chain management', Supply Chain Management: An International Journal, 1: 15-27.

Klaes, Matthias. 2000. 'The history of the concept of transaction costs: neglected aspects', Journal of the History of Economic Thought, 22: 191-216.

Kumaraswamy, Mohan M. 1997. 'Conflicts, claims and disputes in construction', Engineering, Construction and Architectural Management, 4: 95-111.

Li, Huimin, David Arditi, and Zhuofu Wang. 2012. 'Factors that affect transaction costs in construction projects', Journal of Construction Engineering and Management, 139: 60-68.
Simion-Melinte, Cezar. 'CHARACTERISTICS OF COST MANAGEMENT IN CONSTRUCTION PROJECTS', Descrierea CIP a Bibliotecii Naţionale a României Globalization and intercultural dialogue: multidisciplinary: 811 .

Williamson, Oliver E. 1979. 'Transaction-cost economics: the governance of contractual relations', The Journal of Law and Economics, 22: 233-61.

. 1981. 'The economics of organization: The transaction cost approach', American journal of sociology, 87: 548-77.

Rajeh, Mohammed, J. E. Tookey, and J. O. B. Rotimi "Determining the magnitude of transaction costs in construction procurement systems: An exploratory study." World Building Congress, 2013.

Li, Huimin, David Arditi, and Zhuofu Wang "Determinants of transaction costs in construction projects" Journal of Civil Engineering and Management 21.5 (2015): 548-558.

Lu, Wenxue, Lihan Zhang, and Jing Pan "Identification and analyses of hidden transaction costs in project dispute resolutions" International journal of project management 33.3 (2015): 711-718.

Li, Huimin, David Arditi, and Zhuofu Wang "Transaction-related issues and construction project performance" Construction Management and Economics 30.2 (2012): 151-164.

Farajian, Morteza, and Qingbin Cui "TRANSACTION COST IN PUBLIC-PRIVATE-PARTNERSHIPS"

Li, Huimin, David Arditi, and Zhuofu Wang "Transaction-related issues and construction project performance" Construction Management and Economics 30.2 (2012): 151-164.

Li, Huimin, David Arditi, and Zhuofu Wang "Transaction costs incurred by construction owners" Engineering, Construction and Architectural Management 21.4 (2014): 444-458.

Benham, Alexandra, and Lee Benham "The costs of exchange" 2000): Institutions, Contracts, and Organizations: Perspectives from New Institutional Economics, Edward Elgar, Cheltenham (2001): 367-375.

Antinori, Camille, and Jayant Sathaye "Assessing transaction costs of project-based greenhouse gas emissions trading" Lawrence Berkeley National Laboratory, Berkeley, California (2007).

Greenwood, David, and D. J. Yates "The determinants of successful partnering: a transaction cost perspective." Journal of Construction Procurement 12.1 (2006): 4-22.

Lynch, Theodore D. A transaction cost framework for evaluating construction project organizations. Diss. Pennsylvania State University, 1996.

Rajeh, Mohammed A., John Tookey, and James Rotimi "Procurement selection model: development of a conceptual model based on transaction costs." 
Australasian Journal of Construction Economics and Building-Conference Series-Vol.2.No.2 2014.

Kaming, Peter F., et al. "Factors influencing construction time and cost overruns on high-rise projects in Indonesia." Construction Management \& Economics 15.1 (1997): 83-94.

Williamson, Oliver E. "The economics of antitrust: Transaction cost considerations." University of Pennsylvania Law Review122.6 (1974): 1439-1496.

Arditi, David, and Ranon Chotibhongs "Detection and prevention of unbalanced bids" Construction Management and Economics27.8 (2009): 721-732.

Winch, Graham. "The construction firm and the construction project: a transaction cost approach." Construction Management and Economics 7.4 (1989): 331-345.

De Schepper, Steven, Elvira Haezendonck, and Michaël Dooms "Understanding pre-contractual transaction costs for Public-Private Partnership infrastructure projects." International Journal of Project Management 33.4 (2015): 932-946.

Enshassi, Adnan, and Abed Ayyash "Factors affecting cost contingency in the construction industryContractors' perspective" International Journal of Construction Management14.3 (2014): 191-208.

Wang, Ning. "Measuring transaction costs: an incomplete survey" Ronald Coase Institute, Working Paper 2 (2003).

Ibbs, William, and Ying-Yi Chih "Alternative methods for choosing an appropriate project delivery system (PDS)" Facilities 29.13/14 (2011): 527-541.

Bajari, Patrick, and Steven Tadelis "Incentives versus transaction costs: A theory of procurement contracts." Rand Journal of Economics (2001): 387-407.

Guide, A. User'S "Understanding and Monitoring the Cost-Determining Factors of Infrastructure Projects" (2015).

Zhou, Xiuru, Weili Ye, and Bing Zhang "Introducing nonpoint source transferable quotas in nitrogen trading: The effects of transaction costs and uncertainty" Journal of environmental management 168 (2016): 252-259.

AECOM Consult Incorporated. (2010). "Estimating soft costs for major public transportation fixed guideway projects." Transit Cooperative Research Program Rep. No. 138, Transportation Research Board, Washington, DC

Al-Sobiei, O. S., Arditi, D., and Polat, G. (2005) "Managing owner's risk of contractor default." J. Constr. Eng. Manage., 131(9), 973-978.

Williamson, Oliver E. "Transaction-cost economics: the governance of contractual relations." The Journal of Law and Economics 22.2 (1979): 233-261.

Farajian, Morteza. Transaction Cost Estimation Model for US Infrastructure Public-Private Partnerships. Diss. 2010 .
Ho, S. Ping, and Chun-Wei Tsui. "The transaction costs of Public-Private Partnerships: implications on PPP governance design." Lead 2009 Specialty Conference: Global Governance in Project Organizations, South Lake Tahoe, CA. 2009.

Antinori, C., and Sathaye, J. (2007) “Assessing transaction costs of project-based greenhouse gas emission trading." Lawrence Berkeley National Laboratory Formal Rep LBNL-57315, Berkeley, CA

Arditi, D., and Chotibhongs, R (2009) "Detection and prevention of unbalanced bids" Constr. Manage. Econ., 127 (8), 721-732

Arditi, D., and Pulket, T (2010) "Predicting the outcome of construction litigation using an integrated artificial intelligence model" J. Comput Civil. Eng., 24(1), 73-80

Bajari, P., and Tadelis, S. (2001). "Incentives versus transaction costs: A theory of procurement contracts." RAND J. Econ., 32(3), 387-407.

Brockmann, C. (2001). "Transaction cost in relationship contracting" AACE International Annual Meeting Transactions, AACEI, Morgantown, WV, 1-7.

Dudkin, G., and Välilä, T (2005) "Transaction costs in public-private partnerships: A first look at the evidence." Economic and Financial Rep., European Investment Bank, Kirchberg, Luxembourg

Farajian, M. (2010) “Transaction cost estimation model for us infrastructure public-private partnerships." M.S. thesis, Univ. of Maryland, College Park MD

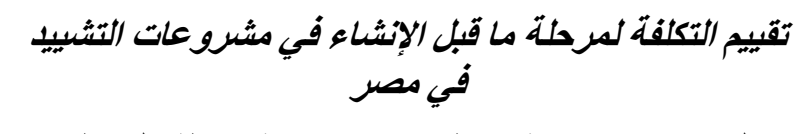

تقام المشروعات الإنشائية في ظروف معقدة وبيئة محاطة بالمخاطر وفي الخان

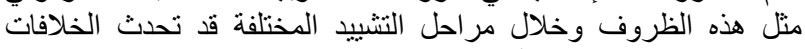

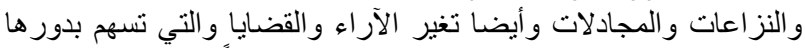

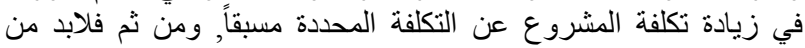
التفريق بين تكلفة الإنتاج و التكلفة المضافة نتيجة التهة هذه المعاملات.

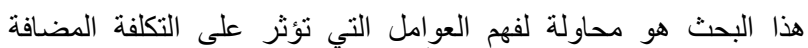

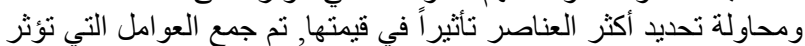

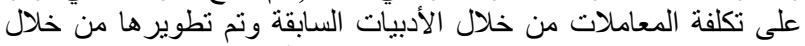

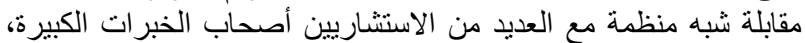

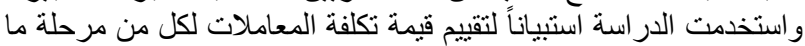

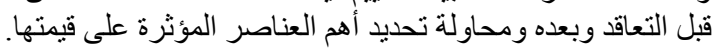

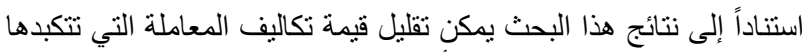

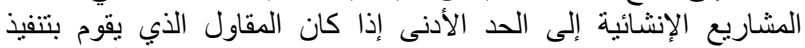

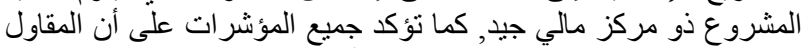

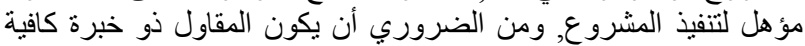

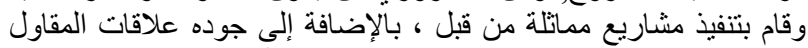

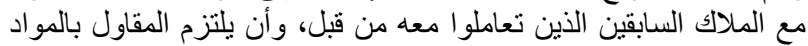

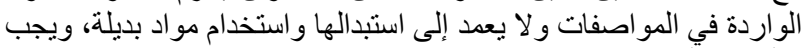

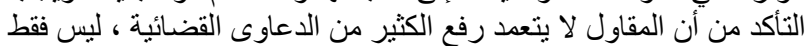

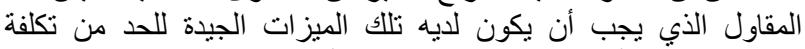

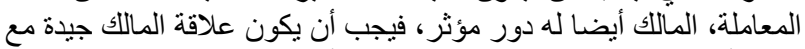

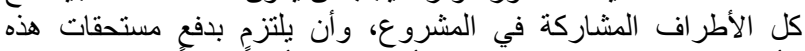

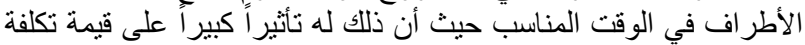

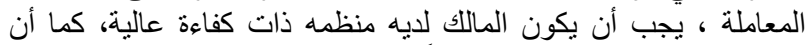

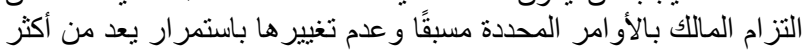

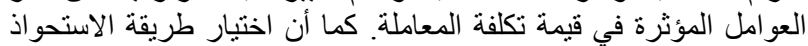




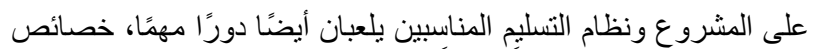

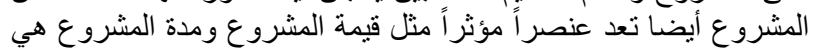

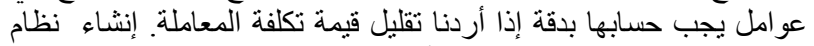

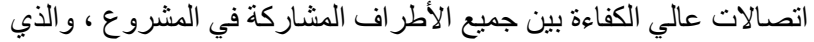

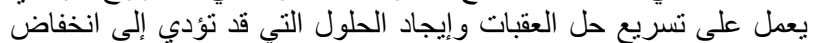

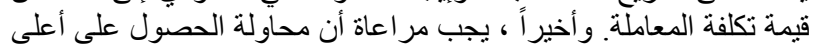

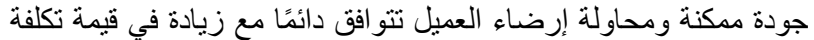

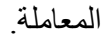

ما يميز هذه الدراسة عن الدراسات السابقة هو أن هذه الدراسة نظرت في ولئ

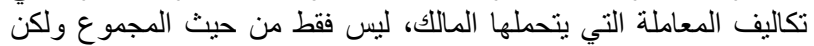

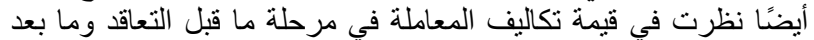
التعاقد بشكل منفصل ودر اسة أيضًا العو امل التي تؤثر علي كل منهما. 